Diosi, P., Babusceac, L., and Gherman, D. Diournal P., Babusceac, L., and David, C., Archio für die gesame Virusforschung, 1967, 20, 383 Diosi, P., and Babusceac, L., American fournal of
Veterinary Research, 1970, 31, 157.

Diabetes Mellitus and Refined Carbohydrate

SIR,-Those of us who have worked in Africa when diabetes appeared to be unWicks and Professor J. J. Jones (31 March, p. 733), who have extended the observation of other doctors ${ }^{1}$ in Salisbury, Rhodesia. They are beginning to elucidate the role of refined carbohydrates as a factor in the pathogenesis of diabetes mellitus.

If one wishes to state the degree of refinement of any starohy carbohydrate, it is desirable to record the crude fibre content; thus maize meal, such as that consumed by Africans in Rhodesia, might vary in crude fibre content from $0.7 \mathrm{~g} / 100 \mathrm{~g}$ if of $60 \%$ extraction to $1.5 \mathrm{~g} / 100 \mathrm{~g}$ if of $96 \% \mathrm{ex}$ traction. That of wheat wholemeal $100 \%$ extraction is $2.0 \mathrm{~g} / 100 \mathrm{~g}$, while white flour $70 \%$ extraction has only a trace, ${ }^{2}$ probably a would be helpful if investigators could state the degree of extraction of the maize meal consumed in Rhodesia. In South Africa recent analysis reported that Bantu preferred maize meal $\mathbf{8 0} \%$ extraction (crude fibre $1.4 \mathrm{~g} / 100 \mathrm{~g}$ ), or $60 \%$ extraction (crude fibre $0.8 \mathrm{~g} / 100 \mathrm{~g})$.

Reports of the experimental production of diabetes mellitus in small rodents seldom mention the crude fibre content of the food offered, though tables ${ }^{2}$ can often supply these figures.

Interpretation has been that excessive calorie intakes encourage obesity and hyperglycaemia. This is correct, but more comprehensive appraisal of the situation suggests that diets rich in undigested fibre have different satiety mechanisms because a larger proportion of the food remain

When an animal feeds on its traditional food, fed ad libitum, it seldom becomes obese or develops diabetes. Perhaps man has a similar response, for refined starchy carbohydrates have not been his traditional food in Africa or in the Western World.-I am, etc., Woodgreen,
near Fordingbridge, Hants

Hugh Trowel and Jones, J. J., Lancet, 1972, 2, 300. Foods Commonly Used in Tropical Countries. Medical Research Council Special Report Series, No. 302, p. 6. London, H.M.S.O., 1971. Metz, J., Lurie, A., and Konidar, M., South
African Medical fournal, 1970, 44, 539.

\section{Insulin and Glucose in Treatment of} Cardiogenic Shock

SIR,-Dr. S. P. Allison and his colleagues (16 September 1972, p. 675) reported the common must congratulate Dr. A. C. B. crude fibre content of about $0 \cdot 1 \mathrm{~g} / 100 \mathrm{~g}$. It undigested in the bowel; less is consumed.

1 Wapnick, S., Wicks, A. C. B., Kanengoni, E.

Platt, B. S., Tables of Representative Values of

value of daily infusions of insulin, glucose, and potassium in cases of severe congestive heart failure. Omitting the potassium, because hyperkalaemia was already present, we have been giving similar treatment to patients in cardiogenic shock after myocardial infarction.

The table shows typical findings in a case of cardiogenic shock before and during the course of one hour after the infusion of glucose $20 \mathrm{~g}$ and insulin $20 \mathrm{U}$ over a period of five minutes. Apart from these results, we have seen diuresis begin after 30 minutes in oliguric cases. Our experience prompts us to recommend glucose and insulin infusions in cases of this kind when immediate lowering of serum potassium concentration and an improvement in cardiac efficiency is required.-We are, etc.,

\section{R. P. BuCKesfeld \\ P. G. LANKIECH H. D. Bolte}

Medizinische Klinik und Poliklinik,

der Universitat,

\section{Prolonged Action of Pindolol}

SIR,-Drs. P. D. Nigam and A. S. Malhotra (24 March, p. 742) reported that in a comparative clinical trial of pindolol and propranolol in angina pectoris they observed a prolonged action of pindolol (Visken, LB 46) for about one week after cessation of treatment. Slome ${ }^{1}$ has suggested that a sudden withdrawal of beta-adrenoceptor blocking drugs might precipitate myocardial infarction in patients with angina pectoris. A prolonged action of pindolol could therefore offer some advantages.

Our studies in human volunteers ${ }^{2}$ showed, in agreement with experiments in anaesthetized dogs, ${ }^{3}$ a significantly longer duration of action for pindolol than for propranolol: $5 \mathrm{mg}$ of pindolol and $100 \mathrm{mg}$ of propranolol were equipotent in reducing the increase in heart rate in response to exercise on the cycle ergometer two hours after oral administration. After eight hours pindolol still elicited $84 \%$ of its full effect and propranolol $67 \%$. After 24 hours the figures were $36 \%$ and $16 \%$ respectively.

While the duration of action of pindolol is clearly longer than that of propranolol there is, however, no pharmacokinetic evidence that pindolol accumulates with prolonged administration. At the end of a 52 week toxicity study in monkeys given oral daily doses of $2.5 \mathrm{mg} / \mathrm{kg}$ and $25 \mathrm{mg} / \mathrm{kg}$ blood levels and urinary excretion data were comparable to those found after a single oral dose of the drug. ${ }^{4}$ Similar results were found in a pharmacokinetic study in man with an oral dose of $5 \mathrm{mg}$ pindolol three times daily for eight days. Blood levels varied within the same range throughout the treatment period and they declined on the last day with the same half-life as after a single dose. ${ }^{5}$ There were therefore no measurable

\begin{tabular}{|c|c|c|c|c|c|}
\hline & $\begin{array}{c}\text { Mean Arterial } \\
\text { Pressure } \\
(\mathrm{mm} \mathrm{Hg})\end{array}$ & $\begin{array}{l}\text { Central Venous } \\
\text { Pressure } \\
\left(\mathrm{cm} \mathrm{H}_{\mathbf{2}} \mathrm{O}\right)\end{array}$ & QRS (sec) & $\underset{\substack{\text { Potassium } \\
(\mathrm{mEq} / \mathrm{l} .)}}{\text { Serum }}$ & $\underset{(\mathrm{mEq} / \mathrm{l} .)}{\text { Blood }}$ \\
\hline $\begin{array}{l}\text { Before infusion } \\
\text { Immediately after } \\
20 \text { minutes after } \\
30 \text { minutes after } \\
60 \text { minutes after }\end{array}$ & $\begin{array}{l}59 \\
60 \\
67 \\
61 \\
71\end{array}$ & $\begin{array}{l}\frac{25 \cdot 5}{2} \\
22 \cdot 5 \\
23 \cdot 5\end{array}$ & $\begin{array}{l}-\overline{0} \\
0 \cdot 12 \\
0 \cdot 10 \\
0.08 \\
0.08\end{array}$ & $\begin{array}{l}7.05 \\
6 \cdot 62 \\
5 \cdot 75 \\
5 \cdot 80 \\
5.05\end{array}$ & $\begin{array}{l}165 \\
223 \\
218 \\
193 \\
193\end{array}$ \\
\hline
\end{tabular}

amounts of pindolol released from the tissues when treatment was stopped.-We are, etc., W. H. AELlig K. SAAMELI

Experimental Therapeutics Department,

Sandoz Ltd.

Basle, Switzerland

1 Slome, R., Lancet, 1973, 1, 156. Slome, R., Lancet, 1973, 1, 156.
Aellig, W. H., British fournal of Pharmacology,
1973, 47, 621P. Saameli, K., Die therapeutische Anivendung $B$ sympathikolytischer Stoffe, ed. H. Dengler. Stuttgart, Schattauer, 1972 .

4 Rentsch, G., unpublished results.
5 Aellig, W. H., and Pacha, W., unpublished results.

\section{Acute Water Intoxication from Compulsive Drinking}

SIR,-Dr. E. R. Alexander and others (13 January, p. 89) reported an interesting case of water intoxication in relation to acute psyohogenic disorder. We have seen a very similar case of acute water intoxication from compulsive water drinking, ${ }^{1}$ and we investigated the patient's water metabolism a week after his admission to hospital, when the intoxication had disappeared. An oral water loading test $(15 \mathrm{ml} / \mathrm{kg})$ was followed by a constant negative concentration of water (as with inappropriate antidiuretic hormone secretion), and this was hardly compatible with the profuse diuresis of low specific gravity observed after his admission to hospital.

To find the reason for this we tried to reproduce the water intoxication by infusing isotonic ( $5 \%$ ) sorbitol at a rate of 1,000 $\mathrm{ml} / \mathrm{hr}$, and every half hour we checked the water concentration. The infusion produced a noticeable lowering of serum osmolality (260 $\mathrm{mOsm} / \mathrm{kg}$ water). Initially the water concentration was negative, and it became positive only when the serum osmolality reached a value below $260 \mathrm{mOsm} / \mathrm{kg}$ water. A similar impairment of the water excreting mechanism was found by Hobson and English. ${ }^{2}$

Water intoxication therefore occurs only when there is impairment of water excretion as well as excessive water intake. Our findings, which differed from those in neurogenic hypernatraemia, ${ }^{3}$ made us think that the water intoxication in our case was due to excessive thirst and a lowered threshold for vasopressin release.-We are, etc.,

\section{LINQUETTE}

P. FosSATI J. LEFEBVRE J. P. CAPPOEN

Service de Médecine Générale et Endocrinologie,

Cité Hospitalière,

Lille, Fr.ince

1 Linquette, M., Fossati, P., Lefebvre, J., Cappoen, J. P., and Chopin, C., Annales d'Endocrinologie,

2 to be published. Internal Medicine, 1963, S8, 324. A. D., New
Mahoney, J. H., and Goodman, A. 279, 1191 .

\section{Artificial Insemination by Donor}

SIR,-May I, as a practitioner of A.I.D., be permitted to comment upon the conclusions of the panel on human artificial insemination chaired by Sir John Peel (Supplement, 7 April, p. 3)?

Selection of Donors.-Medical students, as a group, are not the best donors. The best donor is a man who has fathered two or three healthy children, which is the only 